\title{
Long-Distance Travel and Trading in the Bronze Age: The East Mediterranean-Scandinavia Case
}

\author{
Nils-Axel Mörner'1, Bob G. Lind ${ }^{2}$ \\ ${ }^{1}$ Paleogeophysics \& Geodynamics, Stockholm, Sweden \\ ${ }^{2}$ Archaeoastronomy, Malmö, Sweden \\ Email: morner@pog.nu
}

Received 3 August 2015; accepted 8 September 2015; published 11 September 2015

Copyright (C) 2015 by authors and Scientific Research Publishing Inc.

This work is licensed under the Creative Commons Attribution International License (CC BY). http://creativecommons.org/licenses/by/4.0/

(c) (i) Open Access

\begin{abstract}
Bronze was imported to Scandinavia from the East Mediterranean. This trading started about 1750 BC. At just the same time amber from the Baltic started to appear in Mycenaean and Minoan graves. This gives evidence of active trading between the Mediterranean and Scandinavia. The sudden appearance of picture of large ships cut into bedrock surfaces and blocks at about the same time suggests that this trading took place via visitors arriving by ships. The size of the ships seems to preclude a stepwise transfer via the river systems between the Black Sea and the Baltic, but rather a travel over the Atlantic Sea. This calls for sea-worthy ships and knowledge in geography. In the Bronze Age, only the Mycenaean, Minoan and Phoenician cultures had such ships and such skill. Reaching this far north by $1750 \mathrm{BC}$ in ships following the Atlantic coast of Europe implies that those people may as well have reached much further to the south and the west than previously assumed.
\end{abstract}

\section{Keywords}

The Bronze Age, Travel and Trading, Bronze, Amber, Rock Carvings of Ships, Southern Scandinavia, The Atlantic

\section{Introduction}

Travelling along rivers and multiple river systems was one way of connecting people living far apart in the past. Another way was travelling by ships overseas. This calls for sea-worthy ships and knowledge in geography. In the Bronze Age, only the Mycenaean, Minoan and Phoenician cultures had such ships and such skill. 
In the Aegean and Near East, the Bronze Age began 3300-3000 years BC. For the production of bronze, both cupper and tin were needed. There were a lot of cupper to be found in the East Mediterranean region, not least on Cyprus. However, there was a shortage of tin. Therefore, tin or rather cassiterite ore had to be imported. Cassiterite ore was to be found in Great Britain, northwestern Iberia and southwest France. In Great Britain, the Bronze Age began around $2100 \mathrm{BC}$. This corresponds well with the proposed onset of tin exploitation in Cornwall (Penhallurick, 1986; Haustein et al., 2010). Trading abroad is likely to have commenced at the same time. Tin from Cornwall has been identified in Mycenaean-Minoan bronze objects.

By about 1750 years BC something happened (Figure 1) in Southern Scandinavia, and this is the subject of this paper.

\section{The 1750 BC Sequence of Events}

Scandinavia and Central Europe suddenly stepped into the Bronze Age at about 1750 years BC. The bronze objects were imported from the Mediterranean area (Ling et al., 2014). At just the same time amber started to occur in masses in Mycenaean and Minoan graves (Figure 1). The provenience of that amber is shown to be the south Baltic coasts. This means that we have evidence of a simultaneous import/export exchange between Scandinavia and the Eastern Mediterranean region (Mörner \& Lind, 2010).

At the same time, pictures of huge ships started to be carved into the bedrock and into big blocks in Scandinavia. There are thousands of such rock carvings found and recorded. Throughout the Scandinavian Bronze Age, from 1750 to $500 \mathrm{BC}$, there is an evolutionary trend of those pictures recorded, which may even serve as chronological tool (Kaul, 2000; Ling, 2008). One of those ships is shown in Figure 1(C) (cf. Mörner \& Lind, 2010).

The ships look like nothing known in the local or regional shipbuilding tradition. They are very similar to ships of the same age occurring in the contemporaneous cultures in the Mediterranean, however (Mörner \& Lind, 2008, 2010, 2013). Not only did these cultures have such ships, they also had an advanced knowledge of geography, the shape of the Earth and the motion of the Sun.

Therefore, it seems logical to propose an integrated interpretation, viz. that people from the Mediterranean at about $1750 \mathrm{BC}$, in their excellent ships, reached all the way up to Scandinavia, introducing bronze tools to the region, exporting the valuable amber, and giving the local people reasons to start the new costume of creating rock-carvings of ships (Mörner \& Lind, 2010, 2013).

An oral tradition of a country in the far north named Hyperborea where there was a river of amber termed Eridanos, started to spread in ancient Greece (for example in the story of the Argonauts and their search for the "golden fleece"), and later appeared on their early maps (for example in the world maps of Hekataios from about $500 \mathrm{BC}$ and of Herodotos from about $400 \mathrm{BC}$ ). It seems quite logical to identify Hyperborea with Scandinavia. In SE Sweden, there is a coastal area known as Ravlunda. It is famous for its high amount of amber washed ashore. Amber is in old local language (like in Danish today) named "rav". So, the place name "ravlunda" obviously refers to the content of amber. From a riverbank at Ravlunde, there is an old report of amber in situ (Lind \& Mörner, 2010, 2013; Lind \& Mörner, 2010). Here we may perhaps have the origin of the talk about Eridanos.

In southeast Sweden, we are now able to identify signs and symbols of Mediterranean origin, besides, a central Sun cult and a phallus cult that seem to lead their origin from the Aegean and Near East.
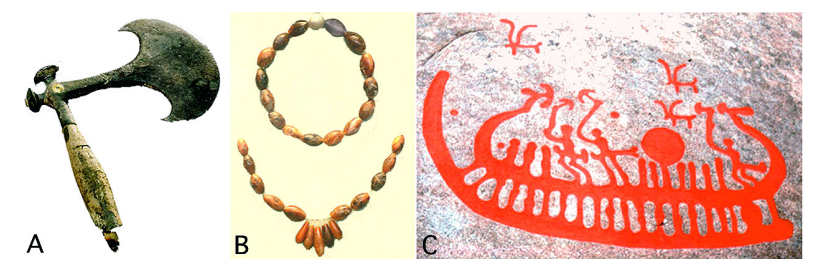

Figure 1. At about 1750-1600 BC three things happened at the same time: Bronze from the Mediterranean appeared in Scandinavia (A); amber from the Baltic (probably Ravlunda) started to appear in masses in Mycenaean graves (B); and pictures of huge ships started to be cut into the bedrock and bronze objects in Scandinavia (C). We interpret this in terms active trading and travel with big ships over the Atlantic from Mycenae in Greece to Tanum and Österlen in Sweden with the establishment of a trading centre in southeast Sweden (Österlen) by Mycenaeans in the Early Bronze Age, later succeeded by the Phoenicians in the Late Bronze Age (Mörner \& Lind, 2008, 2010, 2013; Lind \& Mörner, 2010). 


\section{The Sun Cult}

It is a well-known fact that the Sun was worshiped as a central deity in Scandinavia during the Bronze Age (Montelius, 1911; Almgren, 1927; Bröndsted, 1938). This is evident from extensive pictures in rock-carvings and ornaments on bronze objects, including the famous Sun chariot found in 1902 in the Danish peat bog at Trundholm.

In recent years, we have been able to identify the occurrence of archaeoastronomical observatories in southeast Sweden (Lind, 1996, 2004; Lind \& Mörner, 2010; Mörner \& Lind, 2013; Mörner, 2015). In a way, it is not at all surprising, just another logical sign of the central position of the Sun cult. We are dealing with stone monuments arranged as huge calendars recording the sunrise and sunset at Summer and Winter solstice and at the Spring and Autumn equinoxes, besides the daily motions of the Sun (i.e. sundials).

The $67 \mathrm{~m}$ long stone ship of Ales Stones rests monumentally on the crest of a hill just at the shore at the SE-tip of Sweden (Figure 2). It is strictly oriented with respect to the Sun's annual motions (Lind \& Mörner, 2010; Mörner, 2015) with the sunset at Summer solstice over the stem-stone and with the sunrise at Winter solstice over the stern-stone. There is a small divergence of about $40 \mathrm{~cm}$ with respect to a perfect alignment. Considering the long-term cyclic changes in the Earth tilt (obliquity), this deviation is consistent with a time of erection of about $700 \mathrm{BC}$, i.e. in the late Bronze Age.

Some $15 \mathrm{~km}$ to the NNE lies another stone ship named Stenhed. It is $50 \mathrm{~m}$ long from stem to stern, and is oriented with respect to the Sun in just the same way as Ales Stones.

Finally, just at Ravlunda where all the amber was to be found, we have a $30 \mathrm{~m}$ wide stone circle termed Heimdall's Stones (Mörner et al., 2009; Mörner \& Lind, 2010). It has strict sightlines as illustrated in Figure 3 of Mörner et al. (2009). Today's deviation with respect to perfect solar alignments suggests an age of about 1200-1400 BC. The individual stones are full of rock-carvings; cup marks, Sun symbols and others marks and symbols, some of which are of non-Scandinavian origin. At the north point, there is a phallus formed by three large stones. This is indicative of a phallus cult just as recorded in many rock-carvings in Sweden (Mörner \& Lind, 2010). The monument of Heimdall's Stones is covered by half a meter of eolian sand. This sand-drift has been dated at 600 BC (Mörner et al., 2009; Mörner, 2015). Close-by, lies the Kivik Grave with its remarkably decorated sepulchral stones (Mörner \& Lind, 2010; Lind \& Mörner, 2010; Goldhahn, 2005, 2013). This grave lies in direct relation to the shore of 1000 BC (Lind \& Mörner, 2010: pp. 14-16).

\section{The Same Basic Geometry behind Stonehenge and Ales Stones}

Stonehenge has a basic geometry consisting of a rectangle (combining the station stones), a circle (the Aubrey Circle) and the line of the first sunbeams at summer solstice. Beside the main form of a ship aligned in NW-SE

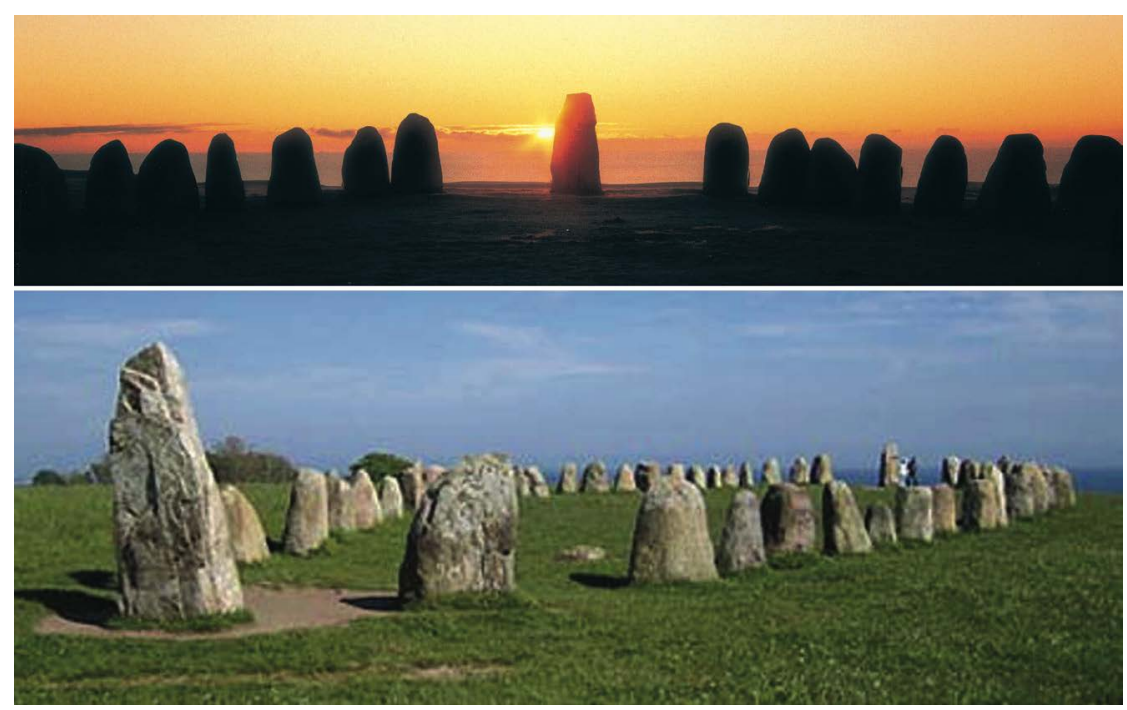

Figure 2. Ales Stones in SE Sweden (Mörner, 2015). Above: Sunrise at winter solstice over the stern stone. Below: General view from the stem stone. 
direction (Figure 2), Ales Stones has a basic geometry consisting of a rectangle, a circle and the line of the first sunbeams at summer solstice. When the Stonehenge picture is superposed on that of Ales Stones, the two basic geometric elements co-inside in details (Mörner \& Lind, 2012). This cannot be a mere coincidence but must imply an active cultural exchange (i.e. travel and trading) between Britain and Scandinavia in the Bronze Age.

Also other facts indicate an active travel and trading in the Bronze Age. This is the case with "the boy with the amber necklace", buried at Boscombe Down, $5 \mathrm{~km}$ SE of Stonehenge, and dated at 1550 BC (Evans et al., 2006; Evans, 2010). The isotopic composition of his milk teeth is indicative of a childhood in the Mediterranean. The 90 amber beads in his necklace have a provenance from the south Baltic coasts. This provides evidence of long-distance migration and trading between the East Mediterranean and Britain as well as between Britain and Scandinavia (Mörner \& Lind, 2010).

\section{Symbols of Foreign Origin}

According to Arbman (1950), a leading Swedish archaeologist in the middle of the last century, the delicate spiral ornament on Nordic bronze objects closely remains of that occurring in Mycenae (below). "Aegean bronzes" are reported from Denmark (Randsborg, 1967). There are plenty of other symbols, however, that seem to lead their origin from the East Mediterranean region; i.e. the Mycenaean, Minoan and Phoenician cultures. Some of those are discussed below. The concentration to Southeast Sweden is clear (Figure 3) and fully in line with the propositionof a Mediterranean trading station there in the Bronze Age (Nilsson, 1875; Mörner \& Lind, 2008. 2010, 2013).

\subsection{The Spiral Ornament}

In Figure 4, we compare the spiral ornament on a piece of bronze jewelry from the grave of "the distant traveller" ("Villfarahögen") at Simrishamn in SE Sweden (left) with the same ornament on a pendant of bronze from the necropolis at Asini in Greece (right). Both objects are dated at about 1600-1700 BC. The ornaments are practical identical. This cannot be a mere coincidence but must imply evidence of a cultural interchange, in one-way or the other (Lind \& Mörner, 2010: p. 55).

\subsection{The Swan Star Constellation on Ales Stones}

Cup marks in the form of the star constellation The Swan is cut into the vertical side of the stone next the stemstone (Lind, 2011). According to the Greek mythology, the people of Hyperborea in the far north worshiped "the white swan", which they held to be messenger of the Sun God. When the Sun sets over the stem-stone at Summer solstice, the Swan constellation is located right above.

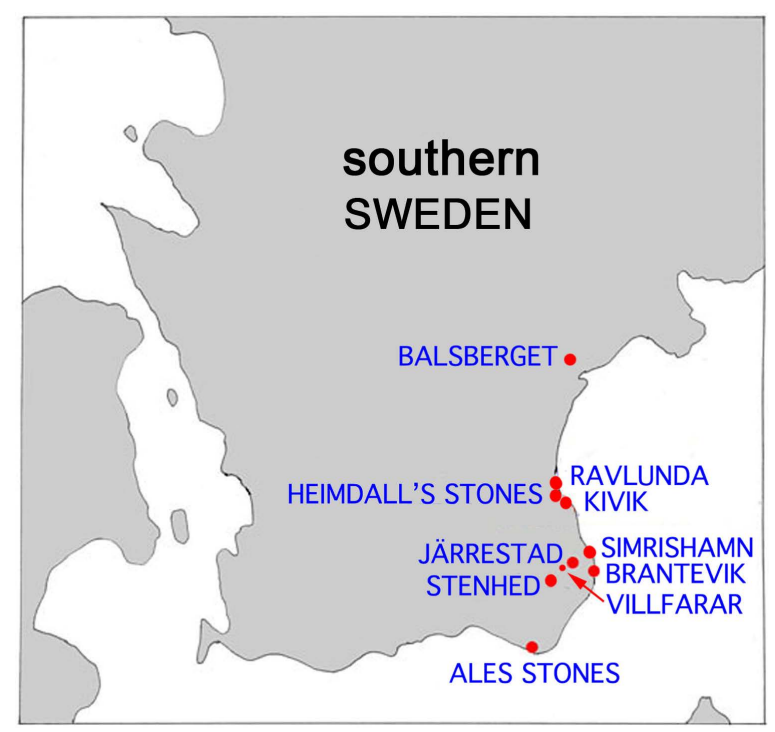

Figure 3. Location of sites mentioned in the text. 

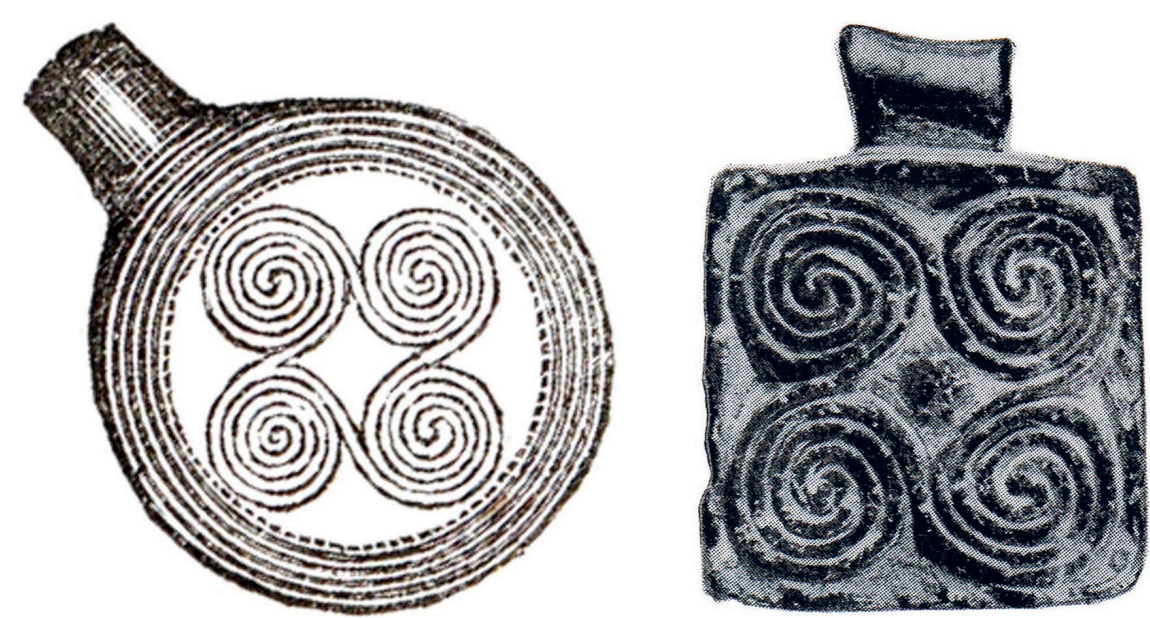

Figure 4. The spiral ornament on objects from Sweden (left) and Greece (right) are practically identical, indicating a cultural interchange between the two regions at about 1600 1700 BC (from Lind \& Mörner, 2010).

\subsection{The Kivik Grave}

The Kivik Grave, also known as the King's Grave, is full of signs and symbols that seem to originate from the East Mediterranean (Mörner \& Lind, 2010, Figure 4; Lind \& Mörner, 2010: p. 57). Therefore, Sven Nilsson already in the 1860s and 1870s proposed that the grave was erected by Phoenician visitors (Nilsson, 1875). The grave was found in 1756, badly destroyed in the 19th century and restored in the 1930s (Goldhahn, 2013). The grave is dated at 1200-1300 BC (Goldhahn, 2005; Mörner et al., 2009). It is located only $60 \mathrm{~m}$ from the fossil shore from around $1000 \mathrm{BC}$ (Lind \& Mörner, 2010). The tomb is composed of 8 large sepulchral blocks with their inner surfaces decorated with pictures, some of which will be discussed below.

In the centre of stone 1, there is a cone that has been interpreted as a Baal sign; that is a sign of Semitic origin that might have been brought here by Phoenician traders (Nilsson, 1875; Lind \& Mörner, 2010). On the same stone there are also two typical Bronze Age axes and a ship.

The picture on stone 5 is today gone, but in two drawings from 1756, there was a flag symbol (Lind \& Mörner, 2010). This symbol is quite unfamiliar to the Nordic region. Similar signs occur in Egypt and in the hieroglyph termed "netjer" implying holy ground. Hence, this flag sign gives strong indications of an influence from the East Mediterranean area in the Bronze Age.

On stone 7, there is a war chariot that has been identified (Marstrander, 1963; Kristensen, 2004) as more or less identical to those used in Mycenae and dated at around 1400 BC (Figure 5). A similar war chariot is cut into the Villfarar-stone at ÖstraTommarp, $18 \mathrm{~km}$ to the south, erected on the top of the grave containing the bronze object with spiral ornament shown in Figure 4 with an estimated age of $1600 \mathrm{BC}$. Both pictures are indicative of a close connection between Mycenae and SE Sweden (as illustrated in our poster to the Santorini meeting in June 2010).

The war chariot, a sign of the Indo-Europeans, on stone 7 in the Kivik grave (left) and the war chariot on the Villfarar-stone (right) from Early Bronze Age (Beckwith, 2009), indicating an active exchange between Mycenaean Greece and southeast Sweden commencing already at 1600 BC.

On stone 8, there are two totally clear omega-signs, never found before in northern Europe (Figure 6). Obviously, they must lead their origin from abroad; be imported or cut by visitors from the Mediterranean (Nilsson, 1875; Mörner et al., 2009; Mörner \& Lind, 2010; Lind \& Mörner, 2010). The omega-sign is older than the Greek letter omega, occurring both in Egypt and in Mesopotamia. Therefore, there is no chronological problem to find it in the Kivik Grave from about 1200-1300 BC.

On stones 7 and 8 , there are scenes of birdlike people that seem to be morning; in procession on stone 7 and beside a sarcophagus on stone 8 (Figure 6; Mörner \& Lind, 2010; Lind \& Mörner, 2010). The motives have been compared with the pictures on the famous HagiaTriada sarcophagus on Crete, which has an age of 1400 BC (Glob, 1969). It might perhaps be interpreted as the nymphs (Heliades) morning the death of Phaeton who fell in the River Eridanos where the tears of the nymphs were transformed into amber (Mörner \& Lind, 2010). 


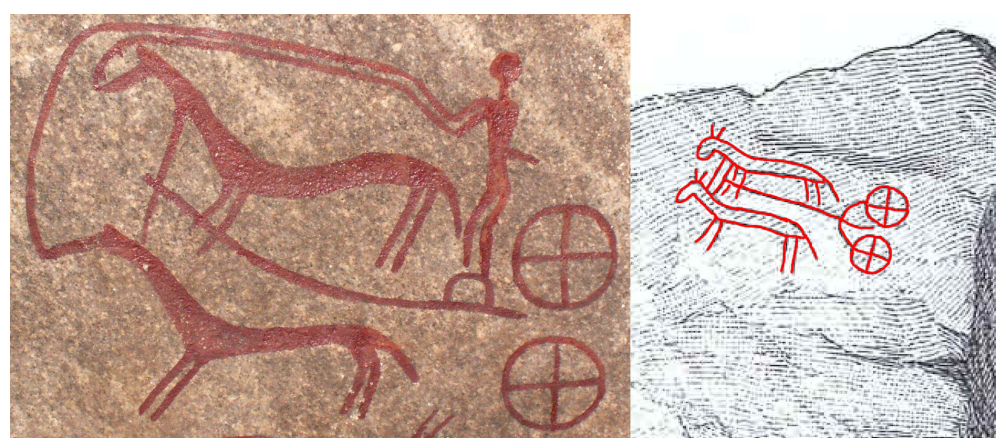

Figure 5. The war chariot, a sign of the Indo-Europeans, on stone 7 in the Kivik grave (left) and the war chariot on the Villfarar-stone (right) from Early Bronze Age, indicating an active exchange between Mycenaean Greece and southeast Sweden commencing already at 1600 BC.

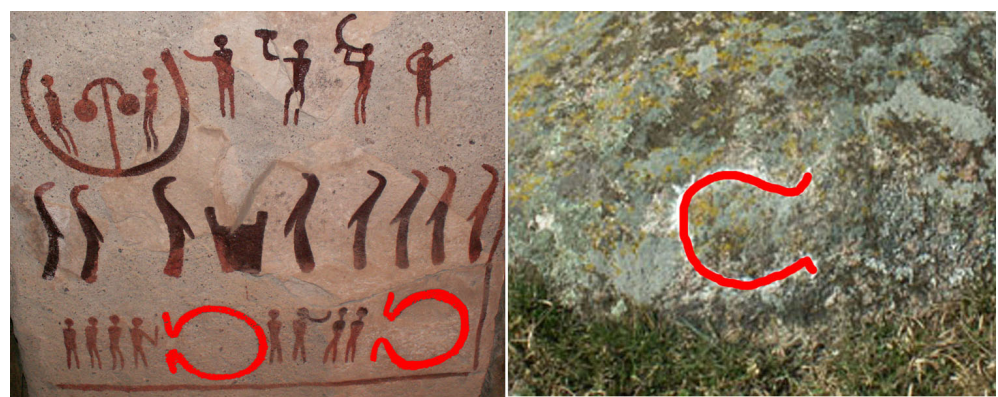

Figure 6. The two omega signs in the Kivik grave (left) and the one at Heimdall's Stones (right).

\subsection{The Heimdall's Stone}

A distinct omega-sign (Figure 6) is deeply cut into one of the blocks of Heimdall's Stones (Mörner et al., 2009; Mörner \& Lind, 2010; Lind \& Mörner, 2010). This sign, like those in the Kivik Grave, obviously leads its origin from the East Mediterranean region. The two omega-signs in the Kivik Grave and the newly found omega-sign in Heimdall's Stones are the only omega-signs known in the whole of Northwestern Europe.

There is also a delta sign interpreted as a Baal-symbol (like the one in the Kivik grave). Besides, one of the sight-stones has been cut in conic or delta shape.

Also a serpent and some fishes that might have a Mediterranean origin are cut into the blocks.

\subsection{The Järrestad Rock-Carving}

There is a famous bedrock surface full of carvings from nearly the whole of the Bronze Age. There is a ship of typical Mediterranean type (Lind \& Mörner, 2010: p. 44). There is also a ship sign that has been interpreted as a miniature of the Ales stone ship (Lind \& Mörner, 2010: p. 88). If this is correct, it implies that Ales Stones itself must be older; i.e. from the Bronze Age just as we propose.

The Järrestad rock surface is full of carvings; ships, feet, shoes and many other symbols. There are 164 feet, pair of feet, shoes and pair of shoes. In order to undertake a proper statistical analysis, all of them were measured as to geographic position. In quite sharp and pointed gauss-curves, $86.8 \%$ were strictly aligned to the sunrise at Winter solstice, $7.6 \%$ at the sunset at the Summer solstice, and only 5.5\% at other directions (Mörner, 2012).

\subsection{The Balsberget "Flag"}

Some $50 \mathrm{~km}$ to the north of Heimdall's Stones there is a bedrock hill named Balsberget (i.e. the hill of Bal). In 2009, we found a distinct "flag" cut into a big block near the top of the hill and close to the entrance to some karstic caves (Lind \& Mörner, 2010). This sign is almost identical to the one found on stone 5 in the Kivik grave, i.e. the Egyptian hieroglyph sign "netjer" (holy ground). Therefore, we believe that the name of the hill (Balsberget) really may refer to the Semitic god Baal. 


\subsection{The Phoenician Pearl}

In the 1930s, a local fisherman, making his daily morning walk along the beach at Ravlunda searching for amber having been washed ashore during the night, found a pearl on the beach. This pearl was later identified as a "Phoenician pearl" by the Swedish crown prince (later to become King Gustaf VI Adolfus), who was an archaeologist by training. This pearl, dating from the Bronze Age, must have been brought to Sweden by trading or by visitors from the East Mediterranean (Mörner \& Lind, 2010; Lind \& Mörner, 2010).

\subsection{The Ale Owl}

In 1953, an owl of amber, about $8 \mathrm{~cm}$ high, was found in the ground $1.5-2.0 \mathrm{~m}$ in front of the stern stone of Ales Stones (Figure 7). It has been kept in the family of the man who found it and no one has known about it. It was shown for the first time on the cover of Lind \& Mörner (2010).

The original lump of amber seems to have resembled an owl with the face toward us and the body in profile. This is precisely the shape of the famous Greek owl from the Bronze Age. The face has been further expressed by the carving of two eyes (leaving a sharp beak in between). With light from behind, the eyes are burning (Figure 7).

\subsection{The Tanumshede Rock-Carving}

In the county of Bohuslän in SW Sweden, there are numerous rock-carvings from the Bronze Age (e.g. Ling, 2008). Ships are a favourite motive and we have already proposed an origin in visiting ships from the East Mediterranean in the Bronze Age (Mörner \& Lind, 2010). Another common motive is men with erected penises, which gives evidence of a phallus cult (op cit., Figure 7).

At the rock-carving site Tanumshede, there are pictures reminding of the famous Minoan game where young men jump vaulting over a bull (Lind \& Mörner, 2010: p. 31). If correctly interpreted, it lends strong support to a Minoan influence.

\section{The Ulunburun Ship}

In1984, an ancient shipwreck was found at a depth of $-44 \mathrm{~m}$ off the Turkish coast at Uluburun (e.g. Pulak, 1998). The ship was dated at about $1300 \mathrm{BC}$. It is a $16 \mathrm{~m}$ long cargo ship. At the time of wreckage, the ship carried an interesting cargo giving evidence of a wide trading (Lind \& Mörner, 2010: p. 37). There were 10 tons of copper from Cyprus, 1 ton of tin of uncertain origin, jewels from Egypt, 1 ton of terebinth resin for perfume in Canaanite jars, glass from Mycenae, ceramics from Cyprus, and large quantities of amber from the South Baltic coasts.

\section{Discussion}

The use of bronze started in Mesopotamia. By about 3000-3300 BC, it had reached the East Mediterranean region. About 1000 years later it was established in Great Britain, and it took an additional 350 years before it reached Scandinavia and Central Europe. These are facts (Figure 8), providing a frame for our interpretations.

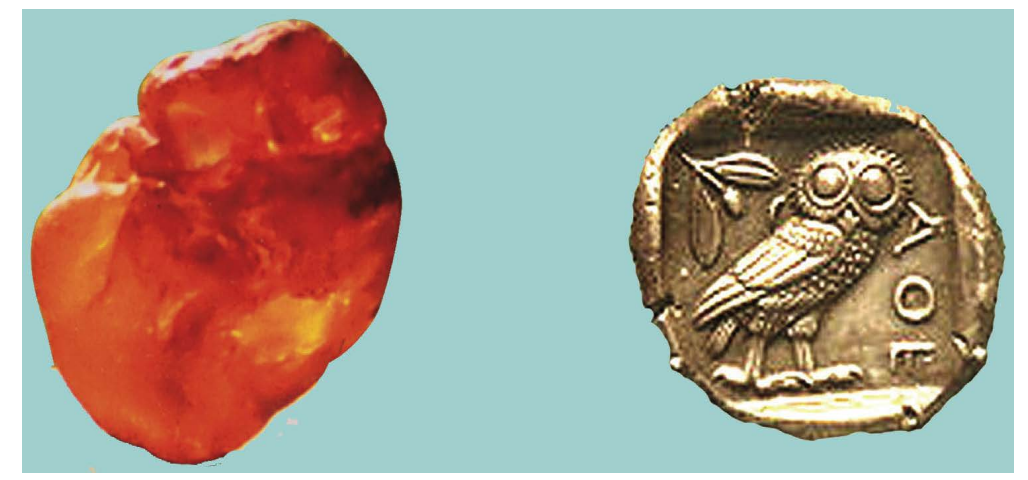

(A)

(B)

Figure 7. The Ale Owl of amber (A) and greece owl on an old coin (B). 


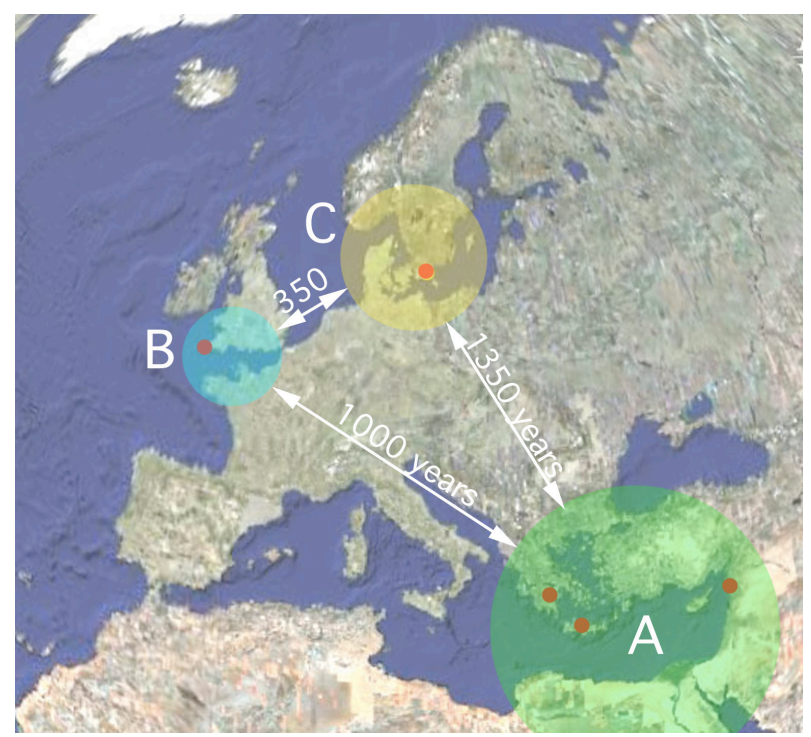

Figure 8. The Bronze Age began at around 3000-3300 BC in area A (the East Mediterranean), at around $2100 \mathrm{BC}$ in area $\mathrm{B}$ (Great Britain) and at around $1750 \mathrm{BC}$ in area $\mathrm{C}$ (Scandinavia). The 1000 years delay between $\mathrm{A}$ and $\mathrm{B}$ and 1350 years delay between $\mathrm{A}$ and $\mathrm{C}$ is indicative of the evolution of trading and travel (Mörner \& Lind, 2010, 2013). The coincidence of events taking place at around $1750 \mathrm{BC}$ in the relations between area $\mathrm{A}$ and $\mathrm{C}$ (Figure 1) suggests an active travel by ships across the Mediterranean, through the Gibraltar and northwards along the Atlantic coasts.

The time lag of the onset of the Bronze Age in the East Mediterranean and in the northwestern parts of Europe is indicative of a general isolation between the three regions (A, B and C in Figure 8) prior to 2100 BC.

At about 2100 BC, the Bronze Age started in Great Britain. This was either due to the opening of trading routs with the East Mediterranean cultures (Mycenaean, Minoan and Phoenician), or due to their own innovation of mixing cupper and tin.

By about 1750 BC, Scandinavia and Central Europe went into the Bronze Age. Obviously, this was a function of the establishment of active trading routs between the East Mediterranean and Scandinavia (Mörner \& Lind, 2010). At the same time Baltic amber started to appear in masses in Mycenaean and Minoan graves. This trading may have gone by small cargo ships via the river systems to the Baltic or by large ships over the Atlantic, or in a combination of both routs. Trading via the river systems is the classical interpretation. Trading over the ocean offers a novel interpretation presented at the Athens meeting in 2008 (Mörner \& Lind, 2008, 2010, 2013).

The sudden appearance of rock-carvings in Scandinavia at around $1750 \mathrm{BC}$ depicting huge ships is tempting to explain in terms of ships from the East Mediterranean reaching Scandinavia over the Atlantic (Mörner \& Lind, 2008, 2010, 2013). This seems the only way of explaining the ships seen in the rock-carvings. They look like nothing in the Northwest European ship building tradition, but are very similar to the ships from the Bronze Age in the East Mediterranean region; sometimes even "almost identical" (cf. Section 6.1, below).

It seems significant that at least 3 possible Phoenician anchorages or trading posts have been found along the Atlantic coast of Portugal (Wachsmann et al., 2009). Besides, the trading of tin from Cornwall to the East Mediterranean seems to have been in operation already in the Early Bronze Age (Muhly, 1985). Travel and trading between the East Mediterranean region and Great Britain, and between Great Britain is indicated by "the boy with the amber necklace" found close to Stonehenge carrying amber from Scandinavia and have an isotopic composition in his teeth indicating a childhood in the Mediterranean region (Evans et al., 2006; Evans, 2010).

In the Greek mythology, we have the vivid story of Jason and the Argonauts. The ship Argos was a big ship with 50 ores in the hands of Greek heroes. The first part of the trip is said to have been to the Georgian coast of the Black Sea in order to get hold of the "golden fleece". The second part, the journey home, is quite doubtful and said to have gone via rivers in the west. During this part, they came to Hyperborea and explored "the amber river" Eridanos. Therefore, it has sometimes been argued that they reached the Baltic and in particular the southeast part of Sweden with the rivers and sea coast full of amber (Rudbeck, 1679; Nilsson, 1875; Mörner \& Lind, 2010; Lind \& Mörner, 2010). The ship seems far too big to have been carried from one river system to 
another, however. The ship must have been quite similar to those depicted in Scandinavian rock art (e.g. Figure 1(C)). Therefore, it seems reasonable to advocate a travel over the Atlantic (Mörner \& Lind, 2008, 2010, 2013).

The hypothesis of Atlantic voyages already in the Bronze Age may explain recent discoveries of megalithic constructions on the Azores (Rodrigues, 2015; cf. Rodrigues et al., 2015).

\section{The Ships Used}

The ships depicted in Scandinavian rock carvings and tool ornaments seem to represent big ships used for open water travel, not for narrow river passage including pulling and carrying.

Some of the depicted ships found in Sweden are so similar to others found in Greece that we have to say that they are "almost identical" (cf. Mörner \& Lind, 2010). This is illustrated in Figure 9 for pictures of more naturalistic types (A) as well as quite schematic types (B).

\section{Conclusion}

Bronze was imported to Scandinavia from the East Mediterranean. This trading started about 1750 BC. At just the same time amber from the Baltic started to appear in Mycenaean and Minoan graves. This gives evidence of active trading between the Mediterranean and Scandinavia.

The sudden appearance of picture of large ships cut into bedrock surfaces and erratic blocks at about the same time suggests that this trading took place via visitors arriving in ships. The size of the ships seems to preclude a stepwise transfer via the river systems between the Black Sea and the Baltic, but rather a travel over the sea (Mörner \& Lind, 2010, 2013).

The Sun cult, the phallus cult and the Baal cult seem to have followed the trading from the Mediterranean to Scandinavia. In Southeast Sweden we have several stone monuments that are built as archaeoastronomical calendars and sundials (Lind \& Mörner, 2010). Besides, there are numerous signs and pictures that seem to lead their origin from the Mediterranean region. Therefore, we proposed that there was a Mediterranean trading station in SE Sweden in the Bronze Age.

An active long-distance travelling over the sea beginning at around $1750 \mathrm{BC}$ opens quite new perspectives and possibilities with respect to connections and influences across oceans. The Mycenaean, Minoan and Phoenician cultures had the geographic understanding, the ships and the seamanship to manage long-distance travels over the sea already in the Bronze Age. We, therefore, believe that Figure 1(C) ship depicts one of those ships visiting Scandinavia from the early Bronze Age on, opening active trading and establishing a strong trading centre in Southeast Sweden. Figure 9 illustrates the close similarities in ship images found in Greece and Scandinavia.

Reaching this far north by $1750 \mathrm{BC}$ in ships following the Atlantic coast of Europe implies that they as well may have reached much further south and west than previously assumed. This is where we open a door for extended analyses of long-distance travel and trading in the Bronze Age.

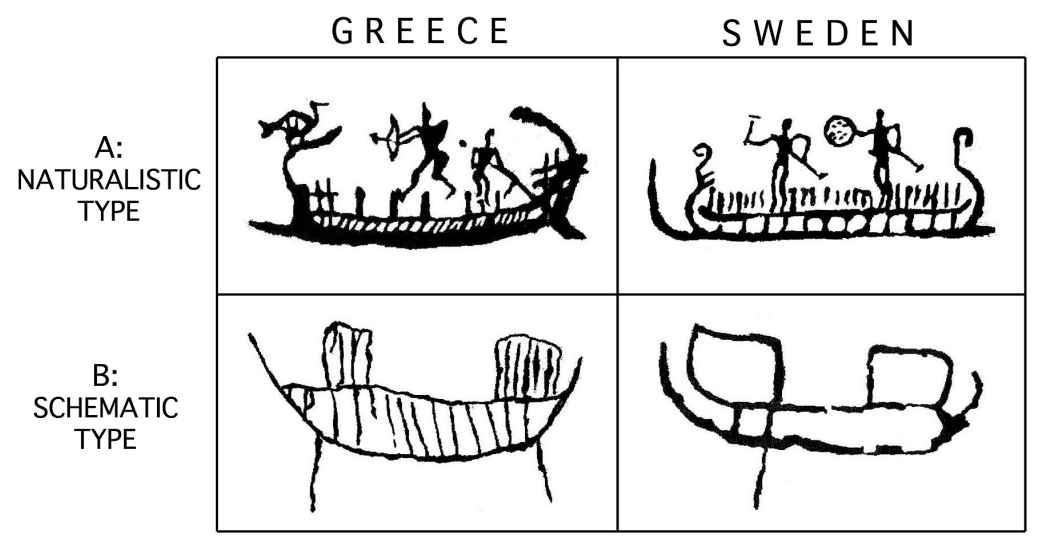

Figure 9. Comparison among pictures of ships found in Greece (left) and Sweden (right) with respect to images of more naturalistic type (A) as well as quite schematic type (B). The similarities are so large that we may even say that they are "almost identical" (cf. Mörner \& Lind, 2010). 


\section{Acknowledgements}

This paper was originally prepared and accepted for the proceedings of "the Atlantis Hypothesis-Commentary 2011" symposium (Edit by S.P. Paraminopoulos) Heliotopos Publications. Due to the general economical problems of Greece, the publication was cancelled, however. The paper is here revised and updated.

\section{References}

Almgren, O. (1927). Hällristningar och kultbruk. Kungl. Vitterhets Historie \& Antikvitets Academiska Handlingar, 35, 23-31.

Arbman, H. (1950). Review of Professor Holger Arbman's Work. In I. Löfström (Ed.), Detta är Österlen (p. 77). Simrishamn: Grafiska Förlaget.

Beckwith, C. I. (2009). Empires If the Silk Road (472 p). Princeton \& Oxford: Princeton Univ. Press.

Bröndsted, J. (1938). Bronzealderens soldyrkelse. Køpenhavn: Gyldendal.

Evans, J. A. (2010). Stonehenge Boy Was from the Mediterranean, the Boy with Amber Necklace: Bronze Age Teenager Buried at Stonehenge Had Travelled to Visit Site from the Mediterranean. http://www.bgs.ac.uk/staff/profiles/0394.html

Evans, J. A., Chenary, C. A., \& Fitzpatrick, A. P. (2006). Bronze Age Childhood Migration of Individuals near Stonehenge, Revealed by Strontium and Oxygen Isotope Tooth Enamel Analysis. Archaeometry, 48, 309-321. http://dx.doi.org/10.1111/j.1475-4754.2006.00258.x

Glob, P. V. (1969). Hellristninger i Denmark. Odense: Andelstryckeriet.

Goldhahn, J. (2005). Bredarör i Kivik. Nya analyser och dateringar av människoben. Fornvännen, 100, 97-100.

Goldhahn, J. (2013). Bradarör på Kivik—En arkeologisk Odyssé (640 p). Simrishamn: Artes Liberales.

Haustein, M., Gillis, C., \& Pernicka, E. (2010). Tinisotopy: A New Method for Solving Old Questions. Archeometry, 52, 816-832. http://dx.doi.org/10.1111/j.1475-4754.2010.00515.x

Kaul, F. (2000). Ships on Bronze. A Study in Bronze Age Religion and Icongrphy. Norwegian Archaeology Review, 33, 6164. http://dx.doi.org/10.1080/00293650050202637

Kristensen, K. (2004). Långferder og hallristninger. Göteborg: Arkeologiska Skrifter.

Lind, B. G. (1996). Solens skepp och Ales stenar. Gudasymbol, astronomisk helgedom, solårskalende och solvisare. Malmö: Stjärnljusets Förlag.

Lind, B. G. (2004). Ales stenar ur ett arkeoastronomiskt perspektiv. Malmö: Stjärnljusets Förlag.

Lind, B. G. (2011). En utredningom Ales stenar. Malmö: Stiernljusets Förlag.

Lind, B. G., \& Mörner, N.-A. (2010). Mykenskaoch Feniciska spar på Österlen. Malmö: Stiernljusets Förlag.

Ling, J. (2008). Elevated Rock Art. Towards a Maritime Understanding of Rock Art in Northern Bohuslän, Sweden. GOTARC Serie B, Gothenburg Archaeological Thesis 49, 1-271.

Ling, J., Stos-Gale, Z., Grandin, L., Hjärthner-Holdar, E., \& Persson, P.-O. (2014). Movingmetals II Provenancing Scandinavian Bronze Age Artefacts. Journal of Archeological Science, 41, 106-132. http://dx.doi.org/10.1016/j.jas.2013.07.018

Marstrander, S. (1963). Östfolds jordbruksristniger i Skeberg. Oslo 1963.

Montelius, O. (1911). Solguden och hansdyrkan. Nordisk Tidskrift.

Mörner, N.-A. (2012). Strict Solar Alignment of Bronze Age Rock Carvings in SE Sweden. Journal of Archaeological Science, 39, 3301-3305. http://dx.doi.org/10.1016/j.jas.2012.05.027

Mörner, N.-A. (2015). Ales Stones in SE Sweden: A Solar Calendar from the Late Bronze Age. Journal of Archaeological Science: Reports, 3, 437-448. http://dx.doi.org/10.1016/j.jasrep.2015.04.002

Mörner, N.-A., \& Lind, B. G. (2008). A Mediterranean Bronze Age Trading Centre in SE Sweden? 33rd International Geological Congress, Oslo, 6-14 August 2008, Abstracts, IEA-01.

Mörner, N.-A., \& Lind, B. G. (2010). A Mediterranean Trading Centre in Southeast Sweden. In S.P. Paraminopoulos (Ed.), The Atlantis Hypothesis - Commentary 2008 (pp. 685-699). Santorini: Heliotopos Publications.

Mörner, N.-A., \& Lind, B. G. (2012). Stonehenge Has Got a Younger Sister. Ales Stones Decoded. International Journal of Astronomy and Astrophysics, 2, 23-27. http://dx.doi.org/10.4236/ijaa.2012.21004

Mörner, N.-A., \& Lind, B. G. (2013). The Bronze Age in SE Sweden-Evidence of Long-Distance Travel and Advanced Suncult. Journal of Geography and Geology, 5, 78-91.

Mörner, N.-A., Lind, B. G., \& Possnert, G. (2009). Heimdall's Stones at Vitemölla in SE Sweden and the Chronology and Stratigraphy of the Surroundings. Geografisla Annaler, 91A, 205-213.

http://dx.doi.org/10.1111/j.1468-0459.2009.00364.x 
Muhly, J. D. (1985). Sources of Tin and the Beginning of Bronze Metallurgy. American Journal of Archaeology, 89, 275291. http://dx.doi.org/10.2307/504330

Nilsson, S. (1875). Spår efter fenisiska kolonier i Skandinavien. Svenska Fornminnesföreningens Tidskrift, 3, 1-39.

Penhallurick, R. D. (1986). Tin in Antiquity: Its Mining and Trade throughout the Ancient World with Particular Reference to Cornwall. London: The Institute of Metals.

Pulak, C. (1998). The Uluburun Shipwreck: An Overview. The International Journal of Nautical Archaeology, 27, $188-224$. http://dx.doi.org/10.1111/j.1095-9270.1998.tb00803.x

Randsborg, K. (1967). Aegean Bronzes in a Grave in Jutland. Acta Archaeologica, 38, 1-27.

Rodrigues, A. F. (2015). Megalithic Constructions Discovered in the Azores. Archaeological Discoveries, 3, 51-61. http://dx.doi.org/10.4236/ad.2015.32006

Rodrigues, A. F., Martines, N. O., Ribeiro, N., \& Joaquinito, A. (2015). Early Atlantic Navigation: Pre-Portuguese Presence in the Azores Islands. Archaeological Discoveries, 3, 104-113. http://dx.doi.org/10.4236/ad.2015.33010

Rudbeck, O. (1679). Atlantica sive Manheim. Uppsala.

Wachsmann, S., Dunn, R. K., Hale, J. R., Hohlfelder, R. L., Conyers, L. B., Erenwein, E. G., Sheets, P., PienheiroBlott, M. L., Castro, F., \& Davis, D. (2009). The Palaeo Environmental Context of Three Possible Phoenician Anchorages in Portugal. The International Journal of Nautical Archaeology, 38, 221-253. http://dx.doi.org/10.1111/j.1095-9270.2009.00224.x 